\title{
OBSERVATION FOR WATER BODIES AND CONTROL FOR THEIR CONDITION
}

\author{
A. Filatov \\ Russian Information and Analytical and Research Water Management Center \\ Rostov-on-Don, Russian Federation \\ fgurostov61@yandex.ru
}

The urgent problem of water objects monitoring is considered. Since providing the population with quality drinking water is one of the most important factors of health protection, the automated information system for state monitoring of water objects of the Russian Federation, developed in the North Caucasus branch of the Russian Scientific Research Institute of Integrated Use and Protection Water resources, has a great scientific and practical value both for monitoring and management of water bodies, and in general for nature protection and human health. The primary information obtained in the result of water bodies and their water protection zones observations and then coming from various water user organizations in accordance with the approved regular observations program form a significant data set, which is the basis of the established unified information base using AIS SMWO. The water body observations program is a list of mandatory actions for the selection and analysis of samples in the water area used by the water user. The owners of water bodies and water users should deliver an annual report on the observations, which indicates the morphometric characteristics of water bodies, and the state of ecosystems of water protection zones and erosion processes, and also the degree of anthropogenic pressure on water bodies. The article describes in detail the forms of relevant information submission for the given base formation by water users, the list of indicators for which is determined by the corresponding Order of the Ministry of Natural Resources and Ecology of the Russian Federation.

Key words: water bodies, water protection zones, water consumption, monitoring of water bodies, automated data system.

\section{[Филатов А.А. Наблюдение за водными объектами и их водоохранными зонами и контроль их состояния] \\ Исследуется актуальная проблема мониторинга водных объектов. Так как обеспечение} населения качественной питьевой водой относится к числу важных фракторов охраны здоровья, автоматизированная информационная система государственного мониторинга водных объектов (АИС ГМВО) Российской Федерации,разработанная в Северо-Кавказском филиале Российского научно-исследовательского института комплексного использования и охраны водных ресурсов (СевКавНИИВХ), имеет большое научное и практическое значение как для мониторинга водных объектов и управления ими, так и в целом для охраны природы и здоровья человека. Первичные сведения, получаемые в результате наблюдений за водными объектами и их водоохранными зонами и затем поступающие от различных организаций-водопользователей в соответствии с утвержденной программой регулярных наблюдений, образуют значительный массив данных, лежащий в основе созданной единой информационной базы с использованием АИС ГМВО. Программа наблюдений за водным объектом представляет собой перечень обязательных действий по отбору и анализу проб в используемой водопользователем акватории. Собственники водных объектов и водопользователи должны сдавать ежегодный отчет по проведенным наблюдениям, в котором указываются морфометрические характеристики водных объектов, а также описывается состояние экосистем водоохранных зон и эрозионных процессов, а также степень антропогенной нагрузки на водные объекты. Подробно описаны формы представления водопользователями соответствующей информации для формирования данной базы, перечень показателей для которых определен соответствующим Приказом Министерства природных ресурсов и экологии Российской Федерации.

Ключевые слова:водные объекты, водоохранные зоны, водопользование, мониторинг водных объектов, автоматизированная информационная система.

Anton A. Filatov - leading engineer. Russian Information and Analytical and Research Water Management Center. Rostov-on-Don, Russian Federation. 
ФилатовАнтонАлександрович -ведущийинженер.Российский информационно-аналитический и научно-исследовательский водохозяйственный центр. г. Ростов-на-Дону, Россия.

Russiaisone of the most water-rich countries: there are more than 30 thousand $\mathrm{m}^{3}$ of water per one inhabitant in a year. The river runoff is the basic source of water resources, its main value is that it can be renewed. In the national economy of the country in quantitative terms water consumption exceeds the total use of all other natural resources. In our country there are over 120 thousand of rivers with a total volume of $4,691 \mathrm{~km}^{3}$, the most part of this volume $(4,538 \mathrm{~km} 3)$ is formed within Russia, and 153.2 $\mathrm{km}^{3}$ comes from the territories of adjoining states.A special feature of water consumption in Russia is a small water diversion from the natural water bodies, no more than $3 \%$ of river flow. At the same time, in a number of regions there is an acute shortage in water resources, conditioned by their mottles distribution on the territory. To the European part of Russia, where about $80 \%$ of the population and industrial potential are concentrated, $8 \%$ of water resources fall within. The structure of water consumption is characterized by the following manner: manufacturing needs $-58,9 \%$; household-drinking needs $-21,0$ $\%$; irrigation - 13,0 \%;rural water supply - 1,6\%; the other needs $-5,5 \%$. Currently, due to the pollution or contamination, about $70 \%$ of Russia's rivers and lakes have lost their quality as sources of drinking water supply, as a result, about half of the population consumes contaminated low-quality water [2].

The state policy of the Russian Federation in the field of the use and protection of water bodies is built considering existing environmental problems and contemporary challenges.According to the Water Code of the Russian Federation [3], the state monitoring of water bodies is a system of observations, assessments and forecasts of changes in the state of water bodies in federal ownership, property of the subjects of the Russian Federation, municipal property, property of individuals, legal entities and appears to be the part of the state environmental Monitoring (state environmental monitoring). The state monitoring of water bodies is carried out in order to: 1) timely detection and forecasting of the negative processes development, affecting water quality and condition of water bodies, development and implementation of measures to prevent harmful consequences of these processes; 2) performance evaluation of realized measures to protect water bodies; 3) information support for the management of water bodies, including for state control and supervision over the use and protection of water bodies.

Water use is any type of activity that is carried out by the direct interaction with a water body (for instance, navigation, fishing, parking of boats, dredging operations in the water area, etc.). According to the contract of water use, the right to use water objects that are in federal ownership is obtained. When concluding a water use contract, an obligatory condition for the water user is the presence of an approved program of the water body regular observations. Monitoring of water bodies water protection zones is carried out in accordance with the resolution of the RF government from 10.04.07, No. 219 "About confirmation of the statementabout the water bodies state monitoring implementation". The list of indicators for this is determined by the Order of the RF Natural Resources and Ecology Ministry from 07.05.2008 No 111 "About approval of the forms and order of providing monitoring data, obtained by the participants of the water bodies state monitoring".

The most modern technologies are widely used in the information sphere, the use of automated monitoring systems of water objects became practically mandatory in monitoring of geoinformation systems. According to the Ministry of Natural Resources Order of the RF from February 6, 2008 N 30"On the approval of forms and procedures for 
submitting information, obtained as a result of observations of water bodies, by the interested federal executive bodies, owners of water bodies and water users", the owners of water objects and water users represent information, obtained as a result of observations for water bodies and their water protection zones, to the relevant territorial bodies of the Federal Agency for Water Resources. Information is presented on electronic media in the form of files with a covering letter, which indicates the number of presented files, their names, size, modification dates, and also the volume of presented information (the number of objects, filled lines of data representation corresponding forms). In the presence of technical possibility, presented information is certified with the digital signature.

The observation program for a water body represents a list of obligatory actions on selection and analysis of probes in the used water area. All obtained data about the object and itswater protection zone are quarterly or monthly delivered in the form of a report to the regulatory body, with whom the water consumption contract is concluded. Besides, the owners of the water bodies and water consumers should deliver an annual report on conducted observations, wheremorphometric characteristics of the water bodies are indicated, and also the state of water protection zone ecosystems is described (blanched land parcels, grounds for shrub vegetation, grounds for wood andtrees and shrub) and erosion processes (the density of erosional pattern), and also the degree ofanthropogenic load towater bodies.

Until recently, these received data did not come together. It was necessary to create a concept for monitoring the water bodies, complex according to its organized structure, and development of unite informative field (on the basis of data bank using) for all participants of such unification, also providing operation summaries about the state of a controlled water body and available for all participants of the given informational community. As is known, the basis of modern software engineering system analysis of large-scale monitoring tasks is the methodology OLAP-Data Mining, which implements the data storage concept. According to the definition given by one of the authors of this concept, "the data warehouse is a subject-oriented, integrated, unchanging, chronological-supporting data set, organized for the purpose of supporting decisionmaking". The main stages of maintaining the data warehouse are the periodic reception and integration of data in the interests of joint analytical processing and control analytics[1].

Within the frameworks of state water policy realization the specialists of NorthCaucasSRIWE developed the informative system of federal significance in 2013 the automated information system of water bodies state monitoring (AIS SMWB) of Russian Federation with the aim of unite informational space formation on the basis of informational resources unity, obtained during state monitoring of water bodies by organizations of various department participation belonging;informational supplying of regulation process in the sphere of using and protection of water bodies; supplying of state control and supervision for usage and protection of water bodies. The scientific principles of information selection were determined, practical recommendations on the inventory of the alignments and the systematization of the timing of sampling, the choice of measuring horizons, intercalibration of measurement technologies, etc., were given.

Currently AIS SMWO is implemented and successfully operates. The department SWR and SMWO of the Russian Informational-analytical and research water management center is responsible for collecting the above information, constantly realizes large and important work on obtaining, specifying, processing and analyzing the reporting forms for monitoring water bodies from all over. The information about water consumer is containedin the water objects presented by the owners and water consumer forms: the name of the Russian Federation subject, the name of the organization, its 
postal address and organizational and legal form, Vat number, the basin district, the year for which information is provided. Monitoring data are summarized in the following forms: Form 6.1. Data of observations for water objects (their morphometric features), Form 6.2. Data of water bodies water protection zones, Form 6.3. Data of observations for the usage mode of water bodies water protection zones. Form 6.1.contains detailed information about the name of the water body water-resources region (for instance, Yenisei from the confluence of the Abakan river to the Krasnoyarsk waterworks facility), denomination and type are specified (for instance, river, lake, swamp), cross section coordinates, drain characteristics, (maximum, minimum and the average deepness, flow velocity $\mathrm{m} / \mathrm{s}$, flow quantity $\mathrm{m}^{3} / \mathrm{s}$ ); reservoir characteristics (water area square $\left(\mathrm{km}^{2}\right)$, volume (thous. $\mathrm{m}^{3}$ ); maximum depth, average depth). In Form 6.2. the name of the water sector, the name and type of the water body, the location of the site and the geographical coordinates of the observation point are described. Erosion processes are described (erosional pattern density $\mathrm{km} / \mathrm{km}^{2}$ or $\mathrm{m} / \mathrm{m}^{2}$, erosional patternalteration $\mathrm{km}$ or $\mathrm{m}$ ), observation types are pointed out. Water protection zoneecosystem (squares and alteration of blanched sites squats $\left(S_{1}\right)$, sites for shrub vegetation $\left(S_{2}\right)$, sites for wood and trees and shrubs $\left(\mathrm{S}_{3}\right), \mathrm{km}^{2}, \mathrm{~m}^{2}, \%$, are described in this table, the reasons of these alterations are pointed out, for instance, shrub invasion or extraction of timber).

In the Form 6.3. the name, address and requisites of the economic entity are given, the type of economic or other activity is described. The table provides information on compliance with the regime for the use of water protection zones, specifies the dates and grounds for its verification and the conclusion of the supervisory authorities based on the results of this audit. Further details and contents of the issued regulations are introduced (for example, for the purpose of integrated, rational use and protection of water objects, protection of interests of citizens and the state, to bring the quality of sewage to the water facility - the Severchikha swamp to the standards specified in p. 10 of the Decision on granting Water object for use). The form also includes information on the fulfillment of the requirements issued during the previous inspection.

The primary information coming from different water users organizations forms a significant data set, which is the basis of the established unified information base. In the future, this database can have scientific and practical application, can be used for comparisons, analysis and scientific research. For example, in the course of surveys and observations, it is possible to determine areas of development of dangerous erosion processes, prevailing types of channel processes, deformations of river beds in control areas of the examined water protection zones, anthropogenic disturbances. The importance of water bodies is great and diverse, and although water resources are related to renewable resources, one should treat them with great care. Providing the population with high-quality drinking water, meeting hygiene standards, is one of the most important factors of health protection. The appliance of AIS SMWO has the great scientific and practical significance for monitoring of water objects, their regulation and in whole for environment conservancy and person's health.

\section{Лumepamypa}

1. БарсегянА.A. Технологиианализаданных: Data Mining, Visual Mining, Text Mining, OLAR. CПб., 2007.

2. Мидоренко Д.А., Краснов В.С. Мониторинг водных ресурсов. Тверь, 2009.

3. Водный кодекс Российской Федерации от 03.06.2006 № 74-Ф3 (ред. от 28.11.2015) // Собрание законодательства РФ. 05.06.2006. № 23. Ст. 2381. 


\section{References}

1. Barsegyan A.A. Technologies of data analysis: Data Mining, Visual Mining, Text Mining, OLAR.SPb., 2007.

2. Midorenko D.A., Krasnov V.S. Monitoring of water resources. Tver, 2009.

3. Water Code of Russian Federation from 03.06.2006 No 74- $\$ 3$ (edit. From 28.11.2015) // Collection of legislation of RF. 05.06.2006. No 23. Art. 2381. 